\title{
FUNDAMENTAL ETHICS IN ISLAMIC POLITICAL THOUGHT
}

\author{
MUHAMMAD RIZKY HK \\ UIN MATARAM \\ rizkyhamzar@uinmataram.ac.id
}

\section{Abstract}

This article attemps to explore the concept of shura and its possibility to be an ethical foundation of Islamic Political Thought. In order to discuss this issue, the main focus will be directed on two main discussion; The ground concepts of Islamic Political Thought, and The Islamic concepts: shura (consultation) It is already known that shura concepts has been widely interpreted as a theoretical basis for electoral democracy in Islam. The main purpose is to present a more philosopical view of Islamic political thought throught it ethical basis and to show that is possible to enrich the discourse on Islamic political though with ethical concept within Islamic dogma.

Keywords: Shura, Ethics, Islamic Political Thought

\section{A. Introduction}

The dynamics development of Islamic political science leads us to a problematical point. Especially when we discussed the process of scientific integration and hybridization between two different epistemological points. So far, Islamic politics is commonly understood as a form of support for the concept of theocracy which is totally anti-democratic and more identical to totalitarianism system, which then raises an attitude of allergy and suspicion towards 
various discourses and terms discussed in the discourses of Islamic political thought.

This, of course, is not happened without any reason. The discourse that dwells on the historical aspect leads us to be trapped in the view that political Islam only discusses the normative framework of the historical aspect of the Islamic State. Discussions about the caliphate, and the personal ethics of a supreme leader seemed to be the core of the discussion of Islamic politics, without focusing on the essential aspects; the spirit of Islamic political thought itself.

Within the framework of the relationship between Islam and politics, Muslim political thinkers are divided into three'; First, the group that initiated the 'depoliticization' of Islam. This group emphasizes the secularization or separation of religion from political matters, this group argues that religion and the state should be completely separate, and thus rejects the idea that Islam is relevant to politics. Second, thinkers such as Sayyid Qutb, Abul A'la Al Maududy argued that there is a 'typical' Islamic political system. Islam is seen as an 'omnipresence' religion; in the sense of regulating the life of a Muslim and offering solutions to all problems. This group rejects other systems that come from western culture including democracy, which is considered an "un-Islamic" system. Among these positions, there are groups that promote integration between Islam and politics which provide a variety of different in-

${ }^{1}$ Bahtiar Effendy, Islam dan Negara: Transformasi Gagasan dan Praktik Politik Islam di Indonesia, (Jakarta : Democracy Project, 2011), p.11 
terpretations of the political conception of Islam and combine Islam, democracy, socialism, liberalism and nationalism.

On the integrative approach, Islam is considered to have no standard on political and constitutional system guidelines. However, Islam provides a code of ethical values for state life. This group is divided into two camps; those who tend to the concept of liberal democracy and those who prefer the electoral concept. Supporters of the electoral concept tend to emphasize majoritarianism. Within the Islamist movement, this view is among the most popular. On the other hand, supporters of liberal democracy advocate a system with elements of constitutional liberalism and extensive provisions to protect minority rights. In the Islamist movement, the concept of liberal democracy is almost difficult to find.

All the arguments above, including those for the depoliticization of Islam, base most of their justification on the historical theological foundation of Islam. Therefore, it is almost impossible to claim that there is one exclusive Islamic political system. In other words, theoretical interpretations of Islam can essentially be used to support various types of political regimes, from repressive and fascist authoritarianism to tolerant pluralism and liberal democracy.

On the next chapter, this article will discuss the political dimension in islam, based on historical records and the relation between Islamic theological creedo with politics. Afterwards, It will explore the ethical aspect in Islamic political thought, and subse- 
quently, The concept of Shura as an ethical basis in Islamic Political Thought.

\section{B. Political Dimension in Islam}

Based on the previous explanation, we can clearly understand that there is no clear conceptual agreement regarding political Islam, which in the end opens up opportunities for more historical theological reinterpretation. Although basically, it can be agreed that both the Qur'an and Sunnah have provided ethical principles that are relevant to the procedures for administering government.

The Qur'an several times mentions ethical ideas about deliberation (shura), justice ('adl) and egalitarianism (musawah). Some of these principles were clearly practiced in the early Islamic political tradition, particularly during the time of the Prophet Muhammad. Ethics also reflects the prophetic spirit 'liutammima makarima al akhlak', the spirit of moral perfection. This spirit then became the basis for the implementation of Islamic values which became the ethical basis of every political action. ${ }^{2}$

Historically, the emergenc of Islam can initially be classified as a socio-political movement that promotes social justice and political action. Socio-political aspects even appear before the commandments of worship, such as the obligation to establish prayer

${ }^{2}$ Rizky HK, Muhammad. "Membaca Pemikiran Taha Abdurrahman Tentang Etika Politik Islam". Politea : Jurnal Politik Islam 3, no. 2 (August 27, 2020): 273 286. Accessed March 3, 2021.

https://journal.uinmataram.ac.id/index.php/politea/article/view/2339. 
services that appear after 10 years of prophethood. For example, Requests for Muhammad PBUH to leave Islam in exchange for coronation as king of Mecca, Negotiations with the people of Ta'if (a city near Mecca) to provide a homeland/city-state for Muslims, demonstrations to assert and demand legitimacy for a new religious identity (i.e. Muslims) in Mecca and demanded the right to worship at the Kaaba (the holiest shrine for both Arab and Muslim pagans), and negotiations with the Ethiopian king to provide shelter and sanctuary. ${ }^{3}$

Socio-political issues are mentioned at least more than 100 times in the Qur'an, 73 of which relate to denouncing unjust rulers or praising those who protest, or oppose them. Muhammad himself stated that the best jihad was to stand tall before an oppressive ruler, demanding justice and protesting against the injustice of the ruler even at the risk of losing his life. ${ }^{4}$

It is important to note that the initial determination of the Islamic Calendar was not the birthday of Muhammad or the beginning of the revelation, but rather the event of the hijrah, in which Muhammad headed to Medina and was welcomed as the new political leader of the city-state. The first project initiated in Medina was the drafting of a socio-political contract, which could form an early

${ }^{3}$ Muhammad al-Buthi, Fiqh al-Sirah (Jurisprudence of the Biography of the Prophet) (Cairo: Dar al-Fikr, 1980), p. 146.

4 Muhammad al-Ghazali, Fiqh al-Sirah (Jurisprudence of the Biography of the Prophet) (Cairo: Dar al-Kutub al-Haditha, 1976), p. 111. 
constitution, known as Sahifat al-Muwada'a ,5 which recognized every tribe in Medina, recognized other religions, and explained the rules of interaction between ethnic and religious groups. Sahifat describes common defense and security, intergroup ethics, conflict resolution, and special forms of autonomy for Jews regarding their internal affairs. It is difficult, then, to conclude that Islam does not have a political dimension. The theological-historical foundation implies a strong political dimension in the building of Islamic thought. ${ }^{6}$ The socio-political spirit even precedes the series of commands for worship in Islam.

\section{Ethical Aspect in Islamic Political Thought}

Western civilization is known as a "civilization of words" (hadāratu alqawl) or civilization of logos, based on the understanding that humans are talking or rational animals. While in Islam, civilization is built on the basis of civilization of deeds (hadäratu al fi l) or civilization of ethos, with ethics as the basic principal. $\mathrm{Hu}-$ mans have identities that living in two realms, material and spiritual. These two realms can be conceptualized as a relation between humans as Homo politicus (Hayawan siyasiy), and humans as Homo religiosus (Hayawan Mutadayin). The tendency to view humans only from the point of view of hayawan siyasiy, or political animals only,

${ }^{5}$ Ibid

${ }^{6}$ Omar Ashour, "Democratic Islam? Assessing the Bases of Democracy in Islamic Political Thought," https://www.mcgill.ca/mes/files/mes/MJMES9Ashour.pdf 
will plunge humans into cruel, oppressive, and domineering creatures. ${ }^{7}$

In Islamic concept, the revelation (wahyu), the ethical logic, and the deeds cannot be separated and cannot contradict each other. Ethics as the axis that reconstructs the political-philosophical revival of the Arab-Islamic world in particular, and contribute to the formation of a pluralist ethos civilization throughout the world. Ethics is the essence of man and humanity itself. Meanwhile, Religion means ethics itself, which ontologically exists along with human existence. Based on the dictum laa insan bi-ghayr akhlaq, there is no human being without ethics, while ethics is religion itself, and there is no religion without humans. Ethics, becomes the spirit and spirit that fills every religious doctrine (Aqidah) and worship obligations (Sharia). ${ }^{8}$

In the political realm, the western concept was built on the spirit of abolition to the church authority. This spirit then leads to a materialism mindset that does not heed the sacredness of religious values in the pattern of interaction between humans. Fazlul Rahman, for example, stated that democratic society in the West is more inclined towards materialism which leads to rejection of the building of a higher socio-moral order. Muhammad Iqbal also emphasized that Western secularism is just another form of application of the Christian principle of 'give the emperor what he is enti-

7 Taha Abdurrahman, Rūḥ al-diin min dhayq al-'almaniyah ilaa sa'ati alI'timaniyah, (Casablanca : Al-Markaz al-tsaqafiy al-arabiy,2012), p. 27-31

${ }^{8}$ Ibid, p. 153 and 174 
tled to, and give to God what is his due 9 . Western democracy in Iqbal's view does not give space to the ethics and spirituality, although basically it does not reject the overall form and process of western democracy.

In the context of human relations, the ethical dimension in Islamic politics is illustrated through the concept of Shura. Shura can be understood as the basic identity of Islamic politics. This concept is an identification mark that encapsulates Islamic doctrine in the form of the principles of living together. Islamic teachings that emphasize the spirit of social solidarity; elevating human dignity, maintaining human rights both in the individual and communal spheres, caring for and respecting one another, elaborated in the concept of deliberation (syuro).

Islam does not come down to a vacuum space, but to a society that already has a stable cultural system. Islam unites with the primordial Arab culture. The concept of shura did not come as a new tradition that commonly new to the Arabs. Historical records explain the existence of dar al-nadwah, consisting of tribal leaders, influential groups, intellectuals who consult not only on social issues, but also political issues, such as the election of leaders. The legitimacy of shura in Islam refers to two verses in the Qur'an, first in (Qur'an 42: 38) and second in, (Qur'an 3:159). In these two vers-

9 Fazlur Rahman, Prinsip-prinsip Syuro dan Peranan Ulama Dalam Islam, (ed), Muntaz Muhammad, Bandung: Mizan1994), p.125 
es, the Quran emphasizes deliberation as a way of making decisions, and the embodiment of gentleness and is the antithesis of hard and hard-hearted attitudes. ${ }^{10}$

Muhammad Tahir bin Asyur, describes the dialogue between God and the angels at the time of Adam's creation, as a manifestation of Shura. Furthermore, Syaikh Ahmad Raysuni said that shura was the first social practice taught by God to his creatures. In this regard, the practice of shura is an example to be imitated even in relation to previously solved questions, or known answers. ${ }^{11}$ Shura in this case, has a purpose and benefit, which is more than just seeking opinion or advice, but as a command, a form of bestowing honor, and setting an example for others to duplicate shura.

Shura got the theological basis to regulate individual relationships, both with regard to the individual himself, relationships with other individuals. The importance of the practice of Shura in the public sphere becomes clear in the two verses of the Qur'an mentioned earlier. The first describes a group that always consults as a way to solve every problem, the second is in the form of an order to Muhammad PBUH to consult on every public problem faced. al-Qannuji as quoted by Raysuni, explains that this verse shows that they are involved in deliberation regarding any problems or questions they encounter. As a result, there is no privilege and dis-

${ }^{10}$ Ahmad Al-Raysuni, Al-Syuro: The Quranic Principle of Consultation, (London: The International Institute Of Islamic Thought, 2012), p.1-2

${ }^{11}$ Ibid, p.2 
crimination in one particular opinion, all points of view are accepted and considered. ${ }^{12}$

\section{Shura: Ethical Basis in Islamic Political Thought}

Shura literally means 'consultation'. In terms of Islamic political thought, Shura refers to deliberations conducted with the aim of gathering and discussing different opinions on a particular subject in order to reach a common decision. Shura is simply a process in which each party in society consults and consults in resolving socio-political problems. Shura is an integral process in the functioning of Islamic values in the country, through proper collective consultation, the community or its representatives can make and pass laws or decisions that are in accordance with the national interest. Shura is defined as the process through which decisions regarding public affairs are resolved. ${ }^{13}$

Shura in Fachry Ali's view, is translated as an operational mechanism to find a common platform among the plurality of society. The real deliberation is not only an acknowledgment of plurality, but also awareness and action to treat each individual equally and equally which leads to justice. It became clear later, that the

${ }^{12}$ Ahmad Al-Raysuni, Al-Syuro: The Quranic Principle of Consultation, (London: The Institute Of Islamic Thought, 2012), Institute Of Islamic Thought, 2012), p.8

${ }_{13}$ Omar Ashour, "Democratic Islam? Assessing the Bases of Democracy in Islamic Political Thought,"

https://www.mcgill.ca/mes/files/mes/MJMES9Ashour.pdf 
concept of deliberation fostered the development of democracy, and provided it with an ethical foundation in political thought. ${ }^{14}$

The majority of classical jurists and contemporary Islamic scholars regard shura as fardhu (Islamic obligation). In the case of a President, Prime Minister or other person having authority, the order to "consult on all matters of public concern" is a mandatory. This is based on the view that deliberation was still carried out and needed by the Prophet even though with his prophetic status and personal perfection, for others the need for deliberation became clearer and more urgent. Ibn Atiyyah, classifies consultation as an obligation, and classifies it as one of "among the most binding foundations and teachings of Islamic law," after which he continues that it is an unquestionable necessity to dismiss rulers or leaders who do not consult with intellectuals. and pious. Ibn Asyur puts forward the same opinion, for him failure to consult is more fatal than a fasiq act, the actions of a fasiq person do not hurt anyone but himself, while the negligence of someone who fails to consult can endanger the interests of all elements of society. ${ }^{15}$

Therefore, musyawarah (deliberation) becomes a necessity and there is no reason to refuse it. The position of deliberation is also implied in the contemporary western system of freedom which clearly distinguishes it from totalitarianism. Islam and authoritari-

${ }^{14}$ Fachry Ali, "Musyawarah dan Demokrasi sebagai Dasar Etika Politik Islami," Makalah, Disampaikan pada Konferensi Islamic Studies, Dirjen Pendidikan Islam, Kemenag, Palembang, 4 Nov 2008, p. 3

${ }^{15}$ Ahmad Al-Raysuni, Al-Syuro: The Quranic Principle of Consultation, p. 8 
anism in the context of the value of deliberation should be two opposite things. The teachings of Islam with the principles of monotheism, spiritual and social piety, expect the birth of a more humanist individual, in contrast to authoritarianism which is oriented towards oppression between humans.

From the perspective of theologians, Abu Bakr al-Asam (d. 816) for example, argued that the wider community should be among the ahl al-hal and so should the Khawarij. However, most Muslim jurists are more specific by saying that ahl al-hal wa al-'aqd are those who have the shaukah (power or power) needed to induce obedience or, to ensure public approval. The classical view of ahl alhal wa al-aqd shows the dominance of elitism. Shura participants are limited to influential people, including tribal leaders, military commanders, wealthy merchants, tribal elders, clerics, as well as individuals who are known to be intelligent and capable.

The classical version of Shura, in its application, is identical with elitism, and tends to the aristocracy. There are at least three key elements of shura: participants, the mechanism for selecting participants, and the outcome of shura. In historical trajectory, shura participants are known as ahl al-shura (shura people) or ahl al-hal wa al-'aqd. In general, there is no mention of the identity of ahl al-hal in the Qur'an and hadith. Hadith, for example, only provides a general description of 'good leadership', specific explanations are passed on through ijtihad and are the product of political thought by Muslim scholars. 
In special cases, shura participants do not always pass the election. Ijtihad 'Umar bin Khattab, for example, appointed a sixperson shura committee as his successor candidate, and ordered them to choose a successor after consultative deliberation with other Muslim leaders. ${ }^{16}$ After three days of deliberation and consultation with influential military commanders, tribal and Muslim leaders, the committee finally chose 'Uthman Ibn' Affan as the third caliph. In this case, most classical Muslim jurists used Umar's ijtihad as the basis for the shura-based succession argument.

However, as is well known, the entire mechanism is a product of 'Umar's ijtihad and political thought. There is no qath'iy or certain guidance that explains the method of choosing a new leader, both in the Qur'an and Sunnah, and 'Umar does not mention the naqliy arguments for all the election mechanisms he ordered. Based on this, there is an open opportunity to develop a mechanism for selecting a leader or government based on shura, in accordance with the Islamic foundation and historical precedent described above. In addition, there is sufficient space to develop this process into something similar to the mechanism of modern democracy without abandoning Islamic principles.

A third relevant point to discuss is the outcome of the shura, relating to situations where consensus fails to be reached. In this case, controversy arises over how a decision or agreement should be

\footnotetext{
${ }^{16}$ Omar Ashour, "Democratic Islam? Assessing the Bases of Democracy in Islamic Political Thought," https://www.mcgill.ca/mes/files/mes/MJMES9Ashour.pdf
} 
reached. With regard to leadership succession, almost all scholars agree that the number of votes should be the determining factor. However, in other cases, such as policy or legal determinations, there are disagreements. Some Muslim thinkers argue that decisions should be made on the basis of a combination of evidencebased arguments or strong theological scriptural backing, with a consistent attitude of prioritizing the 'public interest' and the 'common good'. This group does not at all emphasize the superiority of the majority. ${ }^{17}$

Another group argues that the majority vote must be the main determining factor if there is a deadlock in determining consensus. In this group's view, if in the election of leaders - which is so important - only, the majority vote becomes the main determinant, then on other issues that are not a priority - the same is also needed. Both groups support their arguments by interpreting texts from the Qur'an and Sunnah, using different means of reading. The second problem concerns the legitimacy of the results of shura. Whether then, the results of the shura are binding, inkracht/shura mulzima or not. If the results of the shura are binding, the ruler must comply with the provisions made by the ahl al-shura, thus the

${ }^{17}$ See: Khalid Abou El-Fadl, "Islam and the Challenge of Democracy", (Princeton University Press, 2004), Ibrahim al-Shatibi, Al-I'tisam (The Adherence) (Beirut: Dar al-Ma'rifa, 1980). and Yusuf Al-Qaradawi, Al-Hulul AlMustawrada, p.77 
condition of checks and balances will be realized by limiting the authority of the ruler. ${ }^{18}$

Although some Islamic scholars consider that the output of syuro is only 'recommended and persuasive', but the obligation to accept the results of the agreement can at least maintain the spirit of syuro as a channel of aspirations that indirectly maintains the balance of power, so as not to be trapped in the monopoly of the will of the ruler Even Abul A'la al-Mawdudi (d. 1979), who is known to be conservative and considers the results of shura only 'recommendations', admits the urgency of limiting and subordination of the rulers to the decisions of shura experts. ${ }^{19}$

In fact, we cannot deny that the shura mechanism is never permanent and final, but continues to evolve as a response to historical dynamics that have changed over time. Contemporary Islamic intellectuals, have tried to provide a strong and applicable theoretical basis, as a tool to change the shura into a more friendly and relevant form to inspire a modern, participatory form of government.

When the shura ethic is widely implemented in the form of participatory government, the fear of the emergence of majority tyranny reminds of the importance of the moral commitment that underlies the process of making a policy in the form of legislation,

\footnotetext{
${ }^{18}$ Khalid Abou El-Fadl, "Islam and the Challenge of Democracy"

${ }^{19}$ Abu al-A'la Maududi, Mabadi' al-Islam wa Falsafah al-Hukum (Cairo: Dar al-Shuruq, 1967): halaman 203.
} 
as important as the outcome of the process itself. Thus, if shura is turned into an instrument of participatory governance, it requires commitment towards key moral goals such as justice and social welfare. In other words, shura should be judged not on the basis of the form of agreement produced, but on the basis of the moral values it represents. This is a barrier that distinguishes the substance of representative institutions in Islam and western parliamentary institutions. Although the concept of shura is not described in a final way, its presence is needed to prevent the emergence of oppression by an authoritarian and unjust government. This is in line with the resistance to the injustice government which was based on lust and arbitrariness.

In a modern perspective, Al-Jabiri explains some basic principles that can develop in the conception of shura, following the times, including; The principle of freedom of expression, the principle of accountability and integration and review against the concept of impunity; The principle of succession and division of authority, the Principle of Neutrality, by avoiding elections based on groups, sects and religions in government positions and duties, and adhering to the principles. ${ }^{20}$

These principles later became the contribution of ethical discourse to the scientific building of Islamic political thought. Shura

${ }^{20}$ Abdurrahim, "Konsep Shura' Menurut Pemikiran Abd Al-Jabiri," dalam Makalah yang Disampaikan di Diskusi Pusat Studi dan Konsultasi Hukum Fakultas Syari'ah UIN Sunan Kalijaga Yogyakarta, Mei 2008, p. 6 
is not only judged in terms of the results, or the consensus that is born, but from the basic principles used in the policy formation process. Syuro, in this case, contributes an ethical foundation, which needs to be developed with the eyes of modernity, so that the basic principles of syuro, such as tasamuh, qisth, ta'ayusy, and musawah get rid of anti-democratic elements such as elitism and authoritarianism, and can be overcome and reinterpreted by way that conforms to modern principles of participatory governance and electoral democracy

\section{E. Conclusion}

The dynamics of Shura and its implementation certainly require a deeper study. The difference in the concept of applying shura provokes attention to the principal values contained in shura. Al-Quran and Hadith as a theological basis in islam, can be a foothold for observers of Islamic politics, to explore the ethical principles of shura in reconstructing the study of Islamic political thought.

Islam in this case, contributes ethical values to the development of political thought, so there needs to be encouragement, so that modernization of shura, or shuracracy can be used as an alternative approach in overcoming major problems such as tyranny of the majority, and answering the possibility of liberalizing shura and expanding the project of 'democratizing Islam '. These points are important to promote compatibility between shura and the concept of democracy in terms of power shift and accountability. 
In the end, the main obstacle to a democratic interpretation of Islam, is the argument in favor of 'divine sovereignty', can be overcome by emphasizing the focus on the sovereignty of Humans who speak on its behalf according to their limited individual opinions, and are influenced by social, political, economic and psychological factors.

\section{References}

Abdurrahman, Taha Rūḥ al-diin min dhayq al-'almaniyah ilaa sa'ati al-I'timaniyah, (Casablanca : Al-Markaz al-tsaqafiy alarabiy,2012)

Al-Buthi, Muhammad, Fiqh al-Sirah (Jurisprudence of the Biography of the Prophet) (Cairo: Dar al-Fikr, 1980)

Al-Ghazali , Muhammad, Fiqh al-Sirah (Jurisprudence of the Biography of the Prophet) (Cairo: Dar al-Kutub al-Haditha, 1976) Ali, Fachry, "Musyawarah dan Demokrasi sebagai Dasar Etika Politik Islami," Makalah, Disampaikan pada Konferensi Islamic Studies, Dirjen Pendidikan Islam, Kemenag, Palembang, 4 Nov 2008

Al-Raysuni, Ahmad, Al-Shura: The Quranic Principle of Consultation, (London: The International Institute Of Islamic Thought, 2012)

Al-Shatibi, Ibrahim, Al-I'tisam (The Adherence) (Beirut: Dar alMa'rifa, 1980).

Yusuf Al-Qaradawi, Al-Hulul Al-Mustawrada, 
Ashour, Omar, "Democratic Islam? Assessing the Bases of Democracy in Islamic Political Thought,"

https://www.mcgill.ca/mes/files/mes/MJMES9Ashour.pdf

Effendy, Bahtiar, Islam dan Negara: Transformasi Gagasan dan Praktik Politik Islam di Indonesia, (Jakarta : Democracy Project, 2011)

El-Fadl, Khalid Abou, "Islam and the Challenge of Democracy", (Princeton University Press, 2004)

Maududi, Abu al-A'la, Mabadi' al-Islam wa Falsafah al-Hukum (Cairo: Dar al-Shuruq, 1967)

Rahman Fazlur, Prinsip-prinsip Shura dan Peranan Ulama Dalam Islam, (ed), Muntaz Muhammad, Bandung: Mizan1994)

Rizky HK, Muhammad. "Membaca Pemikiran Taha Abdurrahman Tentang Etika Politik Islam". Politea : Jurnal Politik Islam 3, no. 2 (August 27, 2020): 273 - 286. Accessed March 3, 2021. https://journal.uinmataram.ac.id/index.php/politea/article/vi ew/2339. 